\title{
Student's Mathematics Anxiety on the Use of Technology in Mathematics Learning
}

\author{
Endang Istikomah ${ }^{1}$, Astri Wahyuni ${ }^{1}$ \\ 1) Department of Mathematics Education, Universitas Islam Riau \\ Corresponding author: endangistikomah@edu.uir.ac.id
}

\begin{abstract}
This study aim to describe the student's mathematics anxiety on the use of technology in mathematics learning. It is a quantitative descriptive research by involving second year students of Mathematics Education Program in Universitas Islam Riau (UIR) who took Technology-based Mathematics Learning course. They were selected based on saturation sampling. Data were collected through questionnaire, in-depth interview and documentation. The results show the high level of each dimension of mathematics anxiety among students. The average score in each indicator of cognitive, affective, and physiological dimension were high. In addition, interview revealed that most of the students expressed their anxiety in the first lecture and when obtained the task of applying particular software in mathematics learning. It is mainly due to unpreparedness and lack of knowledge about the application of software. Based on the results, it can be concluded that the level of students' mathematics anxiety is relatively bigh.
\end{abstract}

Keywords: Mathematics anxiety, Technology-based, Mathematics learning,

\section{Introduction}

The students perceive mathematics as a difficult subject. Cockroft (2014) argued that students grew up without enjoying mathematics at all. It is deemed as an unpleasant, incomprehensible with difficult tasks or problems, and not everyone is good at it. Such feelings may trigger certain nervousness or called as anxiety. Mathematics anxiety is an uncomfortable feeling that arises when facing mathematics problems. It is linked to fears and worries in dealing with specific situations related to mathematics (Ma, 2003; D'Ailly \& Arth in Khatoon \& Mahmood, 2010). Moreover, it adversely affects the student achievement (Meece, 1981; Sherman \& Wither, 2003; Karimi \& Venkatesan, 2009; Khatoon \& Mahmood, 2010; Erdogan et al., 2011). It occurs since such an anxiety leads to the complexity in learning and applying the concept of mathematics (Gleason, 2008).

Lyons and Beylock (2012) asserted that mathematics anxiety has similar symptoms with those suffered by the body for other causes. It is because of the posterior insula, a part of the brain that perceives pain in the body becomes an active part of the brain on the subject with mathematics anxiety, particularly subjects with high mathematics anxiety. Khatoon and Mahmood (2010) disclosed that mathematics anxiety is found in students from primary to higher education. Furthermore, the anxiety level increases in line with the increase in educational level (Jackson \& Leffingwell, 1999; Renga \& Dalla in Herman, 2005). The higher level of mathematics anxiety occurs as the complexity of the materials. Consequently, students should be motivated to have higher sense of confidence in order to solve every problem in mathematics learning.

In fact, mathematics anxiety may lead the candidate of mathematics teachers to be passive in developing competence and eluding any activities related with their expertise. Such an anxiety is actually can be examined from the cognitive, affective and physiological 
dimension. Olaniyan and Salman (2015) reported that students with mathematics anxiety have a propensity to claim that mathematics is a difficult course, dislike mathematics, refuse to do their tasks, even skip the class. It certainly can affect their success in math exams. Choppin (2011) divulged that teachers with mathematics anxiety mainly rely on textbook-based teaching that emphasizes on basic skills and minimal discussion activities. In addition, they are less skillful in applying various strategies of mathematics instructional learning in the classroom (Swars, Daane, \& Giesen, 2007). Alzaber and Amelia (2015) affirmed the significant relationship between student's GPA (learning outcomes) and mathematics anxiety.

The use of technology in learning provides positive contribution for students. Istikomah and Sakinah (2013) suggested that the integration of Software Geometers Sketchpad facilitates students to understand a concept. Nevertheless, the use of technology in higher education inadequately diminished students' mathematics anxiety since they are more worried about not understanding the concept of mathematics, instead of applying such technology. It confirms Irfan (2015), who reported students who are common with gadgets as a learning medium still have high anxiety in learning mathematics. Thus, it can be concluded that gadgets do not significantly contribute to the level of mathematics anxiety. Based on the background, the problem in this study is: how is the student's mathematics anxiety on the use of technology in mathematics learning? Furthermore, the aim of this study is to describe the student's mathematics anxiety on the use of technology in mathematics learning.

\section{Research Methods}

This study is a quantitative descriptive study conducted in April 2017 at Mathematics Education Program in Universitas Islam Riau. The subjects of this study were the second year students of Mathematics Education Program who took Technologybased Mathematics course. It involved 40 respondents selected by saturation sampling. Data collection techniques included questionnaire and interview. Questionnaire consisted of statements related to the main sources of mathematics anxiety. It was adopted from Suharyadi (2003) and had been validated and checked for reliability. The examples of statements in questionnaire are presented in Appendix A. The indicators are presented in Table 1 as follows.

Table 1. Indicators of mathematics anxiety

\begin{tabular}{cl}
\hline Dimension & \multicolumn{1}{c}{ Indicator } \\
\hline \multirow{3}{*}{ Cognitive } & Self-ability \\
& Self-confidence \\
& Difficult in concentration \\
& Fear of failure \\
& Nervous \\
Affective & Unpleasant \\
& Restless \\
& Nausea \\
Physiological & Excessive sweating \\
& Rapid heartbeat \\
& Dizziness \\
\hline
\end{tabular}

In this study, the questionnaire was completed using the Likert-scale (Mardapi, 2008) with four answer choices, namely: Strongly Agree (SA), Agree (A), Disagree (D), and Strongly Disagree (DS). Prior the implementation of instrument, a limited test was 
conducted to examine the validity of the questionnaire, by employing Product Moment formula. In this study, the use of technology in mathematics learning refers to the use and operation of Geogebra and Goemeters Sketchpad. Furthermore, interview was performed to determine the response of students toward the use of Geogebra and Goemeters Sketchpad. It was conducted with structured interview sheets in order to make the interview more focused.

Data analysis technique was quantitative data analysis. It was done descriptively based on the results of questionnaire and interview. Descriptive statistical analysis was to describe data about mathematics anxiety among students in the technology-based learning. Data analysis was analyzed manually by using SPSS 21 Software. In this study, the levels of mathematics anxiety were classified into high, moderate and low category. The grouping of mathematics anxiety level is determined based on the distribution of respondent' answers (Azwar, 2012: 109). In this study, the criteria of the levels of mathematics anxiety are presented in Table 2.

Table 2. Category of Student's Anxiety

\begin{tabular}{cc}
\hline Score & Category \\
\hline $\mathrm{X} \leq(\mu-2.0 \sigma)$ & Low \\
$(\mu-2.0 \sigma)<X \leq(\mu+2.0 \sigma)$ & Moderate \\
$X>(\mu+2.0 \sigma)$ & High \\
\hline
\end{tabular}

Description:

$\mu=$ Mean of student's anxiety obtained from research subjects

$\sigma=$ Standard deviation

Based on previous criteria, derivative criteria were obtained as follows:

Table 3. Category of Student's Anxiety

\begin{tabular}{cc}
\hline Score & Category \\
\hline $\mathrm{X} \leq 62.32$ & Low \\
$62.32<X \leq 99.08$ & Moderate \\
$X>99.08$ & High \\
\hline
\end{tabular}

\section{Results and Discussion}

Research activities were conducted after the completion of learning process, which was by distributing the questionnaires to second year students of Mathematics Education Program, UIR. Questionnaire was intended to determine the anxiety level of students on the use of technology, i.e., Geogebra and Geometers Sketchpad, in mathematics learning. The results are presented in Table 4 below.

Table 4. The Student's Mathematics Anxiety Profile

\begin{tabular}{ccc}
\hline Category & Total (students) & Percentage (\%) \\
\hline High & 37 & 92,5 \\
Moderate & 2 & 5 \\
Low & 1 & 2,5 \\
\hline
\end{tabular}

Table 4 demonstrates that almost all of the students' mathematics anxiety level is high. It should be a serious concern despite of the students' academic ability. Based on the 
results of the interview, most students expressed severe anxiety at the first lecture meeting and when there is software-related task. They stated that their anxiety is due to unpreparedness and lack of knowledge about the application of some software in mathematics learning. Furthermore, the student's mathematics anxiety is examined based on the indicators for each dimension of mathematics anxiety as presented as follows.

\section{Cognitive Dimension}

There are four indicators on the cognitive dimensions of mathematics anxiety. The results of questionnaire for each indicator are presented in Table 5.

Table 5. The Cognitive Dimension of Mathematics Anxiety

\begin{tabular}{ccccccc}
\hline No. & Indicator & Score & $\begin{array}{c}\text { Mean per } \\
\text { Indicator }\end{array}$ & Category & $\begin{array}{c}\text { Mean } \\
\text { Total }\end{array}$ & Category \\
\hline 1. & Self-ability & 461 & 115.25 & High & & \\
2. & Self-confidence & 217 & 108.5 & High & High \\
3. & $\begin{array}{c}\text { Difficult in } \\
\text { concentration }\end{array}$ & 77 & 77 & Moderate & 11.22 & High \\
4. & Fear of failure & 246 & 123 & High & & \\
\hline
\end{tabular}

Based on Table 5, almost all indicators of cognitive dimension of mathematics anxiety are included in the high category. It shows that students are very anxious in solving problems on the use of technology in mathematics learning.

\section{Affective Dimension}

In accordance with the affective dimension, there are three indicators of mathematics anxiety. Based on the results of questionnaire, data recapitulation of each indicator is presented in Table 6.

Table 6. The Affective Dimension of Mathematics Anxiety

\begin{tabular}{clccccc}
\hline No. & Indicator & Score & $\begin{array}{c}\text { Mean per } \\
\text { Item }\end{array}$ & Category & $\begin{array}{c}\text { Mean } \\
\text { Total }\end{array}$ & Category \\
\hline 1. & Nervous & 236 & 118 & High & & \\
2. & Unpleasant & 496 & 124.25 & High & 120.90 & High \\
3. & Restless & 241 & 120.5 & High & & \\
4. & Nausea & 357 & 119 & High & & \\
\hline
\end{tabular}

Table 6 demonstrates all indicators on the affective dimension indicate the student's mathematics anxiety is included in the high category. It means that the students are very anxious in following the learning process and solving problems given by lecturers related with the use of technology in mathematics learning.

\section{Physiological Dimension}

There are three indicators on the physiological dimensions of mathematics anxiety among students. The results of questionnaire of each indicator of physiological dimension are presented in Table 7. Data in Table 7 shows the entire indicators on the physiological dimension indicate the student's mathematics anxiety is classified into the high category. It means that the students are very anxious in following the learning process and solving problems given by lecturers related with the use of technology in mathematics learning. 
Table 7. The Physiological Dimensions of Mathematics Anxiety

\begin{tabular}{|c|c|c|c|c|c|c|}
\hline No. & Indicator & Score & $\begin{array}{l}\text { Mean } \\
\text { Item }\end{array}$ & Category & $\begin{array}{l}\text { Mean } \\
\text { Total }\end{array}$ & Category \\
\hline 1. & $\begin{array}{l}\text { Excessive } \\
\text { sweating }\end{array}$ & 227 & 113.5 & High & \multirow{3}{*}{112.83} & \multirow{3}{*}{ High } \\
\hline 2. & Rapid heartbeat & 209 & 104.5 & High & & \\
\hline 3. & Dizziness & 241 & 120.5 & High & & \\
\hline
\end{tabular}

The findings of this study indicate that the students have a high anxiety level in all dimension in the use of technology in the course. The result of interview showed that most students expressed severe anxiety during the first lecture meeting and when receiving the task related with application of some software. Here, anxiety refers to the curiosity of how the technology-based mathematics learning system, the lack of selfconfidence to complete the task, the fear in presenting the paper directly using the software, and the fear of forgetting the procedure in implementing the software. Nevertheless, such situations could be eliminated after the guidance and direction from the supervisor.

Under the pressure circumstance, the capacity of students in solving the problems demonstrates their actual student's ability. It will be easier for those who are calm and have good ability in solving the problems. Conversely, students with high anxiety level will face difficulty in solving problems. They need to control their anxiety so as not to interfere with their concentration in solving the problems. Uncontrollable anxiety will have diverse impacts on the cognitive, affective, and psychological dimension. The noticeable symptoms are the changes in student's attitudes, i.e., nervous, panic, and nausea.

The level of mathematics anxiety that can be categorized as "high" can be minimized by paying attention to the indicators with high score. Lecturers have a capacity to direct the student's point of view by encouraging their self-confidence. Lecturers can show that the course is fun and provide guidance on a regular basis. In addition, they should start the course with motivation about the need for understanding and knowledge of materials. It is in accordance with Wilson (2009) who suggested that a good understanding and knowledge of mathematics, as well as high confidence in one's competence is a basic need for a teacher. In addition, the participation of other parties is also very helpful in lessening mathematics anxiety (Saputra, 2014). It is expected that in this strategy will reduce student's mathematics anxiety. Why does mathematics anxiety need special attention? Because such an anxiety can affect other learning abilities, especially learning achievement (Zakaria \& Nordin, 2008).

\section{Conclusion}

The findings of this study show the high level of mathematics anxiety of the students of Mathematic Education Program, UIR, particularly in the use of technology in mathematics learning. The indicators include the cognitive, affective, and physiological dimension, in which both of them can be classified into high anxiety level. Anxiety particularly emerges at the first lecture meeting and when there is task that requires the application of some software.

\section{Bibliography}

Abidin, M. Zainal. (2013). Gangguan Kecemasan dalam Belajar Matematika. Retrieved from: http://www.masbied.com/2013/05/07/gangguan-kecemasan-dalam-belajarmatematika/. (20 August, 2017). 
Alzaber and Amelia, S. (2014). Hubungan indeks prestasi kumulatif dengan kecemasan matematika mahasiswa pendidikan matematika FKIP UIR. Jurnal aksiomatik program studi pendidikan matematika FKIP UIR, Vol. 1, No. 2.

Azwar, S. (2012). Sikap Manusia: Teori dan Pengukurannya. Edisi ke 2. Yogyakarta: Pustaka Pelajar.

Choppin, J. (2011). The Role of Local Theories: Teacher Knowledge and Its Impact on Engaging Students with Challenging Task. Mathematics Education Research Journal, 23(5), 5-25.

Cockroft, A., Milne, D., and Anderson, N. (2004). The Third Service Delivery Survey 2003: Final Report. Dhaka: CIET Canada and Ministry of Health and Family Welfare, Government of Bangladesh. Retrieved from: http://www.ciet.org/image/country/bangladesh.html\#1 (14 December, 2011).

Erdogan, A., Kesici, S., and Sahin, I. (2011). Prediction of High School Student's Mathematics Anxiety by Their Achievement Motivation And Social Comparison. Elementary Education Online. Vol 10 (2). No 646-652.

Istikomah, Endang and Sakinah, Nor. M. (2013). Kesan Penggunaan Perisian Geometer's Sketchpad Ke Atas Kefahaman Konsep Matematik Pelajar (The Effects of Using Geometer's Sketchpad on Students' Conceptual Understanding of Mathematics). Jurnal Pendidikan Matematik, Fakulti Pendidikan, UKM, 1 (2), 1-13. ISSN: 2231 9425.

Gleason, J. (2008). Relationship between Pre-service Elementary Teachers" Mathematics Anxiety and Content Knowledge for Teaching. Journal of Mathematics Science and Mathematics Education, 3(1), 39-47.

Herman, T. (2005). Mengajar dan Belajar Matematika dengan Pemahaman, Retrieved from: http:// file.upi.edu/Direktori/D\%20-

20FPMIPA/JUR.\%20PEND.\%20MATEMATIKAA/1 96210111991011\%20\%20TATANG\%20HERMAN/Artikel/Artikel13.pdf. (26 January 2013).

Irfan, Muhammad. (2015). Pemanfaatan Gadget Dalam Pembelajaran Matematika Serta Pengaruhnya Pada Mahasiswa Yang Mengalami Math-Anxiety Di Universitas Sarjanawiyata Tamansiswa Pada Mata Kuliah Persamaan Diferensial. Jurnal Science Tech Vol. 1, No. 1.

Jackson, C.D., and Leffingwell, R.J. (1999). The Role of Instructors in Creating Mathematics Anxiety from Kindergarten through College. Mathematics Teacher, 92(7), 583-586.

Karimi A and Venkatesan S. (2009). Mathematics Anxiety, Mathematics Performance and Academic Hardiness in High School Students. International Journal of Education and Science. 1(1), 33-37.

Khatoon, T. and Mahmood, S. (2010). Mathematics Anxiety Among Secondary School Students in India and its Relationship to Achievement in Mathematics. European Journal of Social Science, 16 (1), 75-86.

Lyons I.M and Beilock S.L. (2012). When Math Hurts: Math Anxiety Predicts Pain Network Activation in Anticipation of Doing Math. PlosOne. 7(10), 1-6.

Mardapi, Djemari. (2008). Teknik Instrumen Tes dan Non Tes. Yogyakarta: Mitra Cendikia.

Meece, J. L. (1981). Individual Differences in The Affective Reactions of Middle and High School Students to Mathematics. Unpublished Doctoral Dissertation, University of Michigan.

Olaniyan, O. M. and Medinat F. Salman. (2015). Cause of Mathematics Phobia among Senior High School Students: Empirical Evidence from Nigeria. Journal of the African Educational and Research Network 1(15): 50-56. Retrieved from: 
http://africanresearch.org/africansymposium/archives/TAS15.1/TAS15.1Olani yan.pdf. (14 October, 2016).

Peker, M. (2009). "Pre-Service Teachers' Teaching Anxiety about Mathematics and Their Learning Styles". Eurasia Journal of Mathematics, Science, \& Technology Education. 5 (4), 335-345.

Peker, M. and Ertekin, E. (2011). The Relationship between Mathematics Teaching Anxiety and Mathematics Anxiety. The Educational Review, 23(1), 213-226.

Saputra, Paulus, Roy. (2014). Kecemasan Matematika Dan Cara Menguranginya (Mathematic Anxiety And How To Reduce It). PYTHAGORAS, Vol. 3(2): 75-84 ISSN 2301-5314.

Sherman, B.F. and Wither, D.P. (2003). Mathematics Anxiety and Mathematics Achievement. Mathematics Education Research Joumal, 15(2), 138-150.

Suharyadi. (2003). Hasil Belajar Matematika: Studi Korelasi Antara Konsep Diri, Kecemasan dan Hasil Belajar Matematika Siswa Siswa SD V, Thesis UNJ.

Swars, S.L., Daane, C.J. and Giesen, J. (2007). Mathematics Anxiety and Mathematics Teacher Efficacy: What is The Relationship in Elementary Pre-service Teacher. School Science and Mathematics, 106(7), 306-315.

Wilson, S. (2009). "Better You Than Me": Mathematics Anxiety and Bibliotherapy in Primary Teacher Professional earning. In Hunter, R., Bicknell, B. and Burgess, T. (Eds.). Crossing divides: Proceedings of the 32nd annual conference of the Mathematics Education Research Group of Australasia (Volume 2) (p. 603-610). Palmerstone North, NZ: MERGA.

Zakaria, E and Nordin N. M. (2008). The Effects of Mathematics Anxiety on Matriculation Student as Related to Motivation and Achievement. Eurasia Journal of Mathematics, Science, \& Technology Education. 4(1). 27-30. 


\section{APENDIX A}

\section{Mathematics Anxiety Questionnaire}

Answer the statements based on your experience and perception. Put an $\mathrm{X}$ in your answer choice:

$\mathrm{SA}=$ Strongly Agree, $\mathbf{A}=$ Agree, $\mathrm{SD}=$ Disagree, $\mathrm{SD}=$ Strongly Disagree

\begin{tabular}{|c|c|c|c|c|c|}
\hline No. & Statement & SA & $\mathbf{A}$ & D & SD \\
\hline 1 & $\begin{array}{l}\text { I am not nervous when my Mathematic lecturer approaches } \\
\text { me. }\end{array}$ & & & & \\
\hline 2 & I get stressed when there is a math quiz on the next day. & & & & \\
\hline 3 & $\begin{array}{l}\text { It is difficult for me to concentrate on using technology in } \\
\text { mathematics learning. }\end{array}$ & & & & \\
\hline 4 & $\begin{array}{l}\text { I blank out identifying procedures in the use of technology in } \\
\text { learning media }\end{array}$ & & & & \\
\hline 5 & $\begin{array}{l}\text { I am relieved when I finish my presentation with technology } \\
\text { learning media }\end{array}$ & & & & \\
\hline 6 & $\begin{array}{l}\text { I am unpleasant when the lecturer gives a task that requires } \\
\text { Geogebra. }\end{array}$ & & & & \\
\hline 7 & I enjoy drawing constructs with Geogebra. & & & & \\
\hline 8 & $\begin{array}{l}\text { I am less interested in Math class since the lecturer explicates } \\
\text { too fast and less understandable. }\end{array}$ & & & & \\
\hline 9 & $\begin{array}{l}\text { I am panic every time the lecturer asks me to solve a problem } \\
\text { using learning media or software. }\end{array}$ & & & & \\
\hline 10 & $\begin{array}{l}\text { I am convinced that I am capable to solve the problems using } \\
\text { Geogebra. }\end{array}$ & & & & \\
\hline 11 & I have nausea during math quiz. & & & & \\
\hline 12 & I am prepared when the lecturer asks over an assignment. & & & & \\
\hline 13 & I am confident that I win the competition of the best score. & & & & \\
\hline 14 & $\begin{array}{l}\text { If I am instructed to solve problem in front of the class using } \\
\text { learning media or software, I never have excessive sweating. }\end{array}$ & & & & \\
\hline 15 & Mathematics is such a difficult course. & & & & \\
\hline 16 & $\begin{array}{l}\text { I have no dizziness even when the problem requires } \\
\text { technology-based learning media. }\end{array}$ & & & & \\
\hline 17 & I love Math since it explores my intellectuality. & & & & \\
\hline 18 & I am nervous every time the class involves learning media. & & & & \\
\hline 19 & $\begin{array}{l}\text { If I am instructed to solve a problem in front of the class, I } \\
\text { am not sure I can do it appropriately. }\end{array}$ & & & & \\
\hline 20 & Despite I have nausea, I will do my best to complete the test. & & & & \\
\hline 21 & $\begin{array}{l}\text { I am panic when the lecturer asks me, "Have you understood } \\
\text { it?" }\end{array}$ & & & & \\
\hline 22 & $\begin{array}{l}\text { I have excessive sweating when I cannot answer the lecturer's } \\
\text { question. }\end{array}$ & & & & \\
\hline 23 & Technology-based Mathematics learning is boring. & & & & \\
\hline 24 & It is easy for me to recall steps in Geogebra. & & & & \\
\hline 25 & $\begin{array}{l}\text { I less understand the material, hence I ask the lecturer about } \\
\text { it. }\end{array}$ & & & & \\
\hline 26 & If I have not understood a material, I will directly ask about it. & & & & \\
\hline
\end{tabular}




\section{APENDIX B}

\section{Interview Questions on the Student's Mathematics Anxiety}

1. What encourage you for taking technology-based mathematics?

2. Are you stressed when working on a problem that requires software?

3. Are you convinced or skeptical in working on problems and tasks assigned to this course?

4. Are you nervous during your presentation?

5. Do you have dizziness or nausea during a quiz?

6. Do you find challenges in this course? If so, what kind of challenges do you find?

7. Have you ever felt restless while studying this course?

8. What do you feel about applying various math software?

9. In applying various software, do you find any constraints? What is it/are they?

10. What do you feel when/during learning material with Geogebra?

11. Are you nervous when the lecturer asks, "Have you understood the material? 